\title{
The Role of Financial Speculation in Copper Prices
}

\author{
Kegomoditswe Koitsiwe ${ }^{1}$, Tsuyoshi Adachi ${ }^{1,2}$ \\ ${ }^{1}$ Akita University, Graduate School of Engineering and Resource Science, Japan \\ ${ }^{2}$ Faculty of International Resource Sciences, Akita University, 1-1,Tegata Gakuen-machi, Akita City 010-8502, Japan \\ Correspondence to: Kegomoditswe Koitsiwe, 1-1 Tegata Gakuen-machi, Akita City, Akita, Japan.
}

\author{
Received: April 7, $2018 \quad$ Accepted: June 11, $2018 \quad$ Available online: June 19, 2018 \\ doi:10.11114/aef.v5i4.3182 URL: https://doi.org/10.11114/aef.v5i4.3182
}

\begin{abstract}
The recently ended rise in commodity price boom and the ensuing spectacular price falls that followed, have inspired an interest among the researchers on the role played by other factors besides the physical supply and demand. This paper examines the role played by financial speculation in copper price boom during the last decade. Using least squares with breakpoints, the results indicate that from January 1993 to December 2016 LME real copper spot prices have been characterized by structural changes and its determinants significantly varies in distinct periods. The results reveal that, financial speculation accentuated copper price moves during the last decade. The results support the conclusion that, fundamentals alone cannot fully explain price moves.
\end{abstract}

Keywords: copper price, LME spot price, structural changes, determinants, speculation

\section{Introduction}

The recent rise in commodity prices and even more so its abrupt end has brought about a debate over the extent to which developments in commodity markets are determined by the fundamental factors of supply and demand. The first explanation cites the dynamic demand by emerging economies, especially China, which is further exacerbated by tight production capacity and relatively small inventories to meet the new demand conditions, as a driver behind commodity price movements (Humphreys, 2010; 2015; Radetzki, 2006; 2013b; 2017).

Another explanation hinges on the observation that financial market partakers are more actively involved in commodity markets, thereby causing divergences from equilibrium price. The main evidence for this explanation is the rapid growth in commodity investments in the past decade by institution, hedge funds and individuals who buy and sell futures and options without ensuing physical transactions. According to FCA (2014) commodity assets under management by financial investors increased in value from about $\$ 13$ billion in 2003 to an astounding $\$ 450$ billion in 2011. It is therefore, reasonable to posit that demand by financial investors was the main cause of the commodity price boom.

Empirical works focusing on the determinants of commodity prices beyond physical supply and demand tend to focus on the oil market. According to Dees et al (2007), OPEC decisions had a profound and direct impact on oil prices. The study investigated the world oil market as a function of OPEC capacity, OECD crude oil inventories, OPEC quotas and oil demand. They found out that oil demand and non-OPEC supply were insensitive to changes in prices. Furthermore, Dees et al (2008) examined other factors that might have contributed to the oil price upsurge between 2004 and 2006 other than supply-demand factor, found most of the increase in oil price during that period could be explained by concerns about future oil market conditions. Current findings on the relationship between the changes in oil prices and speculation in oil futures market are not in agreement. This could be due to different methods employed and different sample periods selected.

According to Cifarelli and Paladino (2009) oil price shifts were negatively related to stock price and exchange rate changes during 1992 to 2008, and speculation indeed had played a significant role in the strong oil price fluctuations in recent years. By investigating information transmission over the global main benchmark crude oil spot markets and futures markets, Kaufmann and Ullman (2009) further found out that the surge in oil price before 2008 resulted from fundamentals and speculation together and conjectured that the mechanism of the oil market might have changed in 2004. Sanders et al. (2004) and Haigh et al. (2006) examined the relationship between non-commercial trader reports of the Commodities Futures Trading Commission (CFTC), found that increasing speculative funds were not the cause of 
the oil price surge in recent years.

On the other hand Stevens (2001) contended that micro managing oil markets is becoming more difficult as the information deteriorates and the drivers of oil prices become unpredictable and at times irrational (pg. 212). Lynch (2002) analysed oil prices figures in different periods from 1859 to 2002 and pointed out that the path of oil prices is currently very different from what it was in the past, and this may imply the existence of some structural changes.

In the particular case of copper, there are numerous models for the market. Fisher et al (1972) is the seminal work in copper. Their model estimated for the period 1948-1968, divides the world into two separate but linked markets. The first market is the United States, where administered prices or producer prices dominated during the period of study. The second market is the rest of the world, based largely on the prices of the London Metal Exchange. Seven equations describe copper supply: five equations for primary production and two equations for scrap production. Four equations describe copper demand in the United States, Europe, Japan and the rest of the world. Although an important purpose of the model was to assess the impact of potential increases in Chilean output on copper prices and Chilean revenues, the model has perhaps been more influential as a standard against which to compare subsequent models of the copper industry. Charles River Associates (1978), in one subsequent model, incorporate exploration and discovery of new reserves into a copper model.

Wagenhals (1984) creates a complete and disaggregated study of the copper market. The analysis includes copper market structure, supply, production capacity, and demand and price formation. Equations of primary supply, mine capacities, total consumption and refined copper consumption, and secondary supply are estimated. Tan (1987) constructed an econometric model for the purpose of long-term projections. The model focus in the market economies with the influence of excess supply and the study covered 1964-1983 periods. The study has shown that the copper market has undergone considerable structural changes and gives support to the notion that copper demand and supply are price-inelastic, and that copper demand has been influenced primarily by the industrial production of the consuming countries.

Vial (1989) also creates a model of the world copper industry characterized by the disaggregation of the production in mineral ore, blister and refined copper. For these three products, the author estimates short run supply functions including the main producers, and investment functions, and the price equations. Valencia (2005) estimated econometric model of the world copper industry incorporating geographically disaggregated equations of production capacity, primary supply and demand for the largest producers and most important consumers of fine copper. The study demonstrated that stockpiling has a less significant influence over price than production cutbacks. As well, a decrease in the Chinese growth rate of industrial production strongly affects the level of total demand and copper price and the copper price is also sensitive to changes in the dollar strength against other currencies.

Analysing these studies, we find out that copper market have been econometrically modelled based on supply, demand as well as physical balancing. In the case of the role of financialization and financial speculation in the price of copper in levels the academic literature is confined to Guzmán and Silva (2017). The authors empirically unified the three main determinants of commodity prices including fundamentals, financial speculation and liquidity to explain copper price moves. The purpose of this paper is to examine the role of financial speculation in the acceleration of copper price moves by providing empirical evidence of financial speculation by quantifying the role of the speculative component in explaining copper price increase. Development of this model led to questions about the market structure and its evolution, resulting in the period analysed divided into different periods based on various developments that precipitated such structural shifts. Understanding the determinants of copper prices is of first-order importance for global economy given that copper is important for the export earnings of several developing countries. Furthermore, there are a large number of industrialized and developing countries that need huge amounts of copper to continue with their process of development.

\section{Determinants of Copper Prices}

It is widely accepted that commodity price moves are determined by fundamental market forces. According to Radetzki (2006); Radetzki and Warell (2017) demand is the typical cause of commodity price moves, and demand shocks caused by unusually fast macroeconomic expansion triggered all commodity booms. Tilton and Guzmán (2016) put forward that the income elasticity of demand determines price in the short run while, in the long run, it is physical supply that determines price. Our study focus on the physical balancing and financial market variables attributed to the copper market.

The increase and decrease of stocks can have substantial effect on short-term supply in mineral commodity markets. Changes in the quantity of mineral commodities stored is of importance for pricing, as these can have a stabilizing as well as destabilizing effect on prices. Stockpiling can stabilize prices if stocks are reduced when prices rise, because the additional supply will limit the price increase. The opposite can also be the case, however, if further price rises are 
anticipated and stocks are built up (Gocht et al. 1988). Therefore, an inverse relationship between stocks and the price of copper is expected.

Like most commodities traded internationally copper prices are settled in US dollar, therefore fluctuations in the US dollar exchange rate index play a critical role in driving copper prices (Valencia, 2005 and Guzman and Silva, 2017). When the dollar strengthens against other major currencies, the prices of commodities tend to drop. Similarly, when the value of the dollar weakens against other major currencies, the prices of commodities generally move higher. The latter case was evident from 2002 to 2007 when the US dollar plunged against the currencies of its major trading partners, while on the other hand copper prices were soaring up.

Recent years have seen a rapid growth in the involvement of investors in the commodity markets, inspiring what is called the 'financialization' of commodity markets. In principle, the financialization of commodity markets is a welcome development as investor's willingness to take long forward exposure can enhance the potential for risk sharing and hedging. It should improve the process of price discovery and contribute to price stability, helping both producers and consumers. But the short-term effects at times may have clouded the longer-term benefits. Financialization does open up the possibility for noise trading and momentum strategies to affect prices. It remains a matter of debate whether such trading played a role in the acceleration of commodity prices between 2005 and 2008 . The literature on the impact of financial speculation on commodity markets is quite extensive, and much of the empirical work has focused on oil (Kaufmann 2011; Kaufmann and Ullman 2009; and Zhang and Yao 2016). Furthermore, it has been argued that part of the price co-movement could be explained by financial market factors since investors in this market tend not to differentiate between commodities and, therefore, acquire them in an aggregate manner, Arezki et al. (2014).

\section{Model and Data}

\subsection{Data}

The monthly data set to evaluate the structural change and the effects of financial market variables on copper prices include observations of real LME copper spot prices, LME stockpile, US dollar exchange rate index, real oil price, and speculation open interest data from January 1993 to December 2016. We use real LME copper spot prices as the dependent variable because it represents the price paid for physical tonnes obtained from a variety of sources. To evaluate the effect of stockpile on copper prices, we collect data on LME copper stockpile available from LME. WTI spot price is used in this study to evaluate the effects of oil market. The data is sourced from the US Energy Information Administration (EIA). The nominal prices have been deflated using the Producer Price Index (PPI) of the USA, taking all the values to constant 2016 dollars.

To measure the effect of speculation on copper price change, copper futures open interest is used. The data is sourced from the Committee of Traders (COT) reports of the CFTC. The US dollar exchange rate (USDX) factor is measured by the US dollar index representing the value of the US dollar against a basket of foreign currencies. The USDX data is from the website of American Federal Reserve Committee. The data used is transformed from weekly to monthly and unit root test results for all variables using Augmented Dickey-Fuller (ADF) test and Phillip-Perron (PP) test are given in Table 1. All the variables have unit root therefore are converted to be stationary by taking the first difference.

Table 1. Unit root tests results

\begin{tabular}{llllll}
\hline & & & & & $\begin{array}{l}\text { Order } \\
\text { integration }\end{array}$ \\
& ADF & & PP & \\
\cline { 2 - 5 } & Level & 1st diff & Level & 1st diff & \\
\hline PRICE & -1.33 & $-11.1^{* *}$ & -1.20 & $-11.1^{* *}$ & I (1) \\
STOCK & -2.34 & $-10.8^{* *}$ & -2.12 & $-19.4^{* *}$ & I (1) \\
USDX & -1.54 & $-11.9^{* *}$ & -1.42 & $-11.9^{* *}$ & I (1) \\
OIL PRICE & -1.95 & $-13.1^{* *}$ & -1.87 & $-12.8^{* *}$ & I (1) \\
OPEN INTER & -0.818 & $-15.0^{* *}$ & -1.26 & $-22.7^{* *}$ & I (1) \\
\hline
\end{tabular}

Note: Table 1 reports the unit root tests for all the variables (null hypothesis: there is a unit root). All the variables have a unit root in levels, but rejected the null hypothesis at 5\% significance level denoted by $* *$.

\subsection{Structural Characteristics of the Copper Market}

Since the variables impact probably change over time, structural breakpoints were taken into account. In our study we consider the data generating process in the copper price with $m$ breaks $(m+1$ regimes);

$$
y_{t}=z_{t}^{\prime} \delta_{j}+u_{t} \quad t=T_{j-1}+1, \ldots, T_{J}
$$

For $j=1, \ldots, m+1$. This is a general model of Bai and Perron $(1998,2003)$ corresponding to a pure structural change model. Here $y_{t}$ is the observed dependent variable at time $t ; z_{t}(q \times 1)$ is a vector of covariates and $\delta_{j}(j=1, \ldots, m+$ 1 ) is the corresponding vector of coefficients; $u_{t}$ is the disturbance at time t. The indices $\left(T_{1}, \ldots, T_{m}\right)$, or breakpoints 
are explicitly treated as unknown. The method of estimation is based on the least squares principle. For each m-partition $\left(T_{1}, \ldots, T_{m}\right)$ the associated least-squares estimates of $\delta_{j}$ are obtained by minimizing the sum of squared residuals.

$$
S_{T}\left(T_{1}, \ldots, T_{m}\right)=\sum_{i=1}^{m+1} \sum_{t=T_{i-1}+1}^{T_{i}}\left(y_{t}-z_{t}^{\prime} \delta_{i}\right)^{2}
$$

Let $\left(\left\{T_{j}\right\}\right)$ denote the resulting estimates based on the given m-partition $\left(T_{1}, \ldots, T_{m}\right)$ denoted $\left\{T_{j}\right\}$.

Our equation specification consists of the dependent variable (LME copper spot price) and a single (constant), and allows for serial correlation that differs across regimes through the use of HAC covariance estimation. We allow up to three breaks in the model, and employ a trimming percentage of $20 \%$.

Bai-Perron tests of L globally optimized breaks against the null hypothesis of no structural breaks along with the corresponding $U D_{\max }$ and $W D_{\max }$ that is Double maximization tests are used to test for the existence of breaks. Bayesian Information Criterion (BIC), Yao (1988) is used to find the number of breaks. According to Hall et al. (2013), BIC criterion provides reliable information for structural breaks inference even in the presence of serial correlation.

Figure 1 shows the three shifts or breaks in November 1997, January 2005 and October 2009 respectively. Through investigating the historical events and market situation around the breakpoints, we could find some relevant evidence economically. The breakpoint in November 1997 corresponds with the period of Asian financial crisis caused by assets bubbles. The impact of Asian regions reduced business activity thus demand was felt in many commodity markets. Among the metals, copper prices declined by 36\% between June 1997 and February 1998 (UNCTAD, 1998). Around this breakpoint commodity markets, copper included suffered from the slowing of global growth. The first reason was the deep economic recession that followed the oil crisis of the late 1970s. The second reason was the economic slowdown and eventual collapse of the Soviet Union. Between 1990 and 2000, the economies of the former Soviet Union shrank in size. Both these developments had a severe negative impact on demand for minerals (Humphreys 2015). There was too much mine capacity and mineral prices were persistently weak and investors had largely lost interest in mining.

The breakpoint in June 2004 coincided with the rapid increase in commodity prices, copper included. The rapid growth in China's demand for minerals prompted a corresponding need for rapidly increased supply. After years of underinvestment the market was unable to respond to the upsurge in Chinese demand. The scale and persistence of the resulting price increases had by 2005 given rise to the notion that commodity markets were embarked on super-cycle driven by expanding demand from China and other emerging market countries. There were also suggestions that a rise in investor interest in commodities was serving to exaggerate price movements. According (Kaufman, 2010; UNCTAD, 2009; Gilbert, 2010) financial speculation was the driver of commodity price boom.

The breakpoint in October 2009 corresponds with the world financial crisis caused by credit crunch. Two peaks occurred in commodity prices in 2008 and 2011, and this is explained by the occurrence of the recession of 2008-2009 triggered by the financial crisis. According to Radetzki and Warell (2017) this crisis made only a short-run impression on the major commodity indices. This is explained by the fact that the recession mainly afflicted the advanced economies, while economic growth among the recently dominant commodity consumers of emerging and developing Asia experienced only a short-dip followed by an impressive recovery.

According to the analysis above, it could be considered that the copper market had undergone 3 structural changes since 1993 to 2016. We therefore divide copper price characteristics into four periods based on the breakpoints: Period 1 (January 1993 to October 1997); Period 2 (November 1997 to December 2004); Period 3 (January 2005 to September 2009) and Period 4 (October 2009 to December 2016). The results are supported by Guzmán and Silva (2017), who identified two breakpoints related to Chinese boom and financial speculation, and financial crisis in a different period of time studied. Our study further identified a breakpoint related to a prolonged deep economic recession, economic slowdown and Asian financial crisis that resulted in too much mine capacity and weak mineral prices. 
Estimation results of the structural change model (January, 1993- December, 2016)

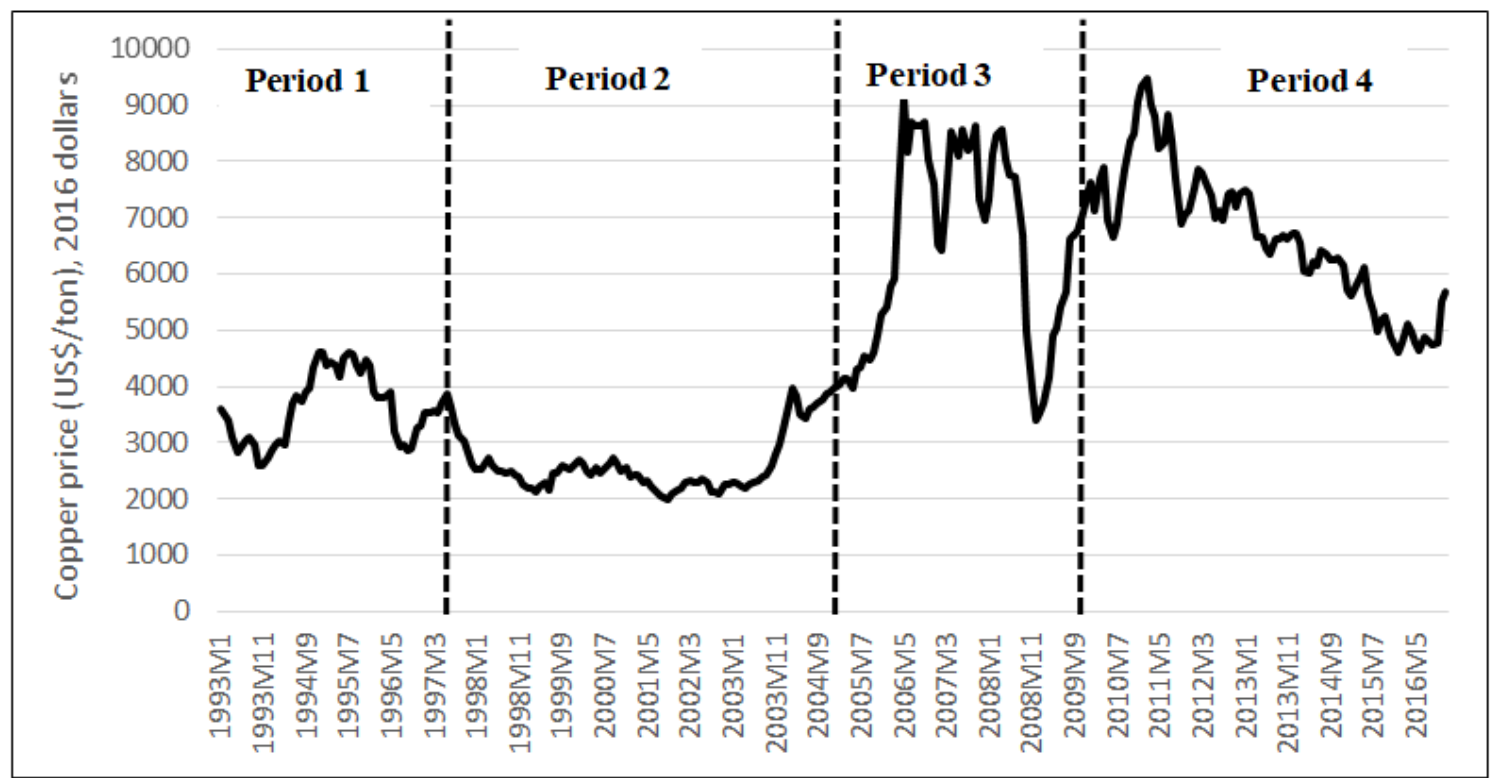

Figure 1. Shows different structural change periods in copper prices.

\subsection{Econometric Analysis of Copper Price Determinants}

To determine the effects of different factors on copper price changes, least squares regression analysis for copper price changes to various drivers is constructed. The model considers the relationship between real spot copper price and copper lagged price (one month lag), copper stockpile, USDX, real oil price and speculation open-interest, and the model is established as follows:

$$
p_{t}=\alpha_{i}+\beta_{o i}(L) p_{t}+\beta_{g i} S_{t}+\beta_{u i} U S D X_{t}+\beta_{p i} O_{t}+\beta_{x i} F_{t}+\varepsilon_{t}
$$

Where $i=1,2,3,4$, corresponds to the four sample periods ("March 1993 to October 1997"; "November 1997 to December 2004"; "January 2005 to September 2009" and "October 2009 to December 2016," respectively; $P_{t}$ is the real LME copper spot price at time $t$; $S$ is the LME stockpile at time $t$; USDX is the US dollar exchange rate index at time $\mathrm{t}$; $\mathrm{O}$ is real WTI crude oil price at time $\mathrm{t}$. F denote open-interest at time $\mathrm{t}$ and $\varepsilon_{t}$ is the error term. All the variables are expressed in first log-differences and $\mathrm{L}$ is the lag operator.

\section{Results}

\subsection{Period 1 (March 1993 - October 1997)}

In period 1 the results indicate that the copper price changes are affected by its lagged price and stockpile only. USDX, oil price and open interest are not significant, which may mean they are not the main driving forces in this period to explain changes in copper price. Specifically, $10 \%$ rise in $\mathrm{P}_{t}(-1)$ is associated with $3.12 \%$ increase in copper price, while an increase in stockpile reduce copper price changes by $1.29 \%$. The diagnostic tests of all the regression models are valid.

\subsection{Period 2 (November 1997 - December 2004)}

In period 2 the results indicate that all variables are not significant to explain copper price changes except its lagged value, $P_{t}(-1)$. Specifically, a $10 \%$ increase in $P_{t}(-1)$ is associated with $3.27 \%$ increase of changes in copper spot price. According to (Plunkert and Jones, 1999) this period has experienced large global surplus partly explained by Asian financial crisis in 1997 and early 2000's economic recession therefore is quite reasonable to have copper price changes explained by its previous historic price.

\subsection{Period 3 (January 2005 - September 2009)}

In this period the adjusted $\mathrm{R}^{2}$ value is $51.3 \%$, and is the highest as compared to other sub-periods. The diagnostic tests are validated for the regression. The $\mathrm{P}_{\mathrm{t}}(-1)$, USDX, oil price and open interest significantly affect the copper price changes. Open interest is significant in this period and also the oil price. Specifically, when open interest increase by $10 \%$, copper price change rise by $2.73 \%$ and $2.78 \%$ for $10 \%$ increase in oil price. All things equal, the results would imply that an increase in open interest would have a positive effect assuming a direct causality. The results indicate that financial speculation played a role in the acceleration of copper prices. Our results further indicate that oil price has a 
positive effect together with financial speculation, which could support the view that financial speculation explains part of co-movement of commodity prices.

\subsection{Period 4 (October 2009 - December 2016)}

Copper price change are significantly affected by price (-1), and USDX. Diagnostic tests are valid. Price (-1) positively affect copper price changes, whereas USD had a negative effect. Specifically, $10 \%$ rise in price (-1) resulted in $1.80 \%$ increase in copper price changes. While a $10 \%$ increase in USDX is associated with $13.54 \%$ decrease in copper price changes. As compared to Period 3, speculation and oil price are not significant in this period. This could be explained by financial crisis, which according to Radetzki and Warell (2017) had a short-run impression on the major commodity indices.

Table 2. Shows the results.

\begin{tabular}{|c|c|c|c|c|}
\hline & Period 1 & Period 2 & Period 3 & Period 4 \\
\hline $\begin{array}{l}\text { Constant } \\
\mathrm{P}_{\mathrm{t}}(-1)\end{array}$ & $\begin{array}{l}-0.000814 \\
(0.913) \\
0.312 * * \\
(0.0125)\end{array}$ & $\begin{array}{l}0.00405 \\
(0.385) \\
0.327 * * * \\
(0.0019)\end{array}$ & $\begin{array}{l}0.00278 \\
(0.7903) \\
0.261 * * \\
(0.0196)\end{array}$ & $\begin{array}{l}0.00331 \\
(0.5085) \\
0.1802 * \\
(0.0712)\end{array}$ \\
\hline $\mathrm{S}$ & $\begin{array}{l}-0.129 * * * \\
(0.0054)\end{array}$ & - & - & - \\
\hline USDX & - & - & $\begin{array}{l}-1.517 * * \\
(0.0175)\end{array}$ & $\begin{array}{l}-1.354 * * * \\
(0.0001)\end{array}$ \\
\hline $\mathrm{O}$ & - & - & $\begin{array}{l}0.273^{* *} \\
(0.0234)\end{array}$ & - \\
\hline $\mathrm{F}$ & - & - & $\begin{array}{l}0.277 * * \\
(0.0191)\end{array}$ & - \\
\hline $\begin{array}{l}\text { Adj. R-sq. } \\
\text { D-W } \\
\text { LM test }\end{array}$ & $\begin{array}{l}0.230 \\
2.00 \\
0.229\end{array}$ & $\begin{array}{l}0.110 \\
2.09 \\
0.236\end{array}$ & $\begin{array}{l}0.513 \\
1.97 \\
0.991\end{array}$ & $\begin{array}{l}0.218 \\
1.88 \\
0.605\end{array}$ \\
\hline $\begin{array}{l}\text { Heteroscedasticity } \\
\text { test }\end{array}$ & 0.882 & 0.655 & 0.226 & 0.339 \\
\hline
\end{tabular}

Note: "-" indicates that the variable is not significant even at the $10 \%$ level and is removed from the equation. The numbers in parentheses represent probability. $* * *, * * *$ represents that a statistic is significant at the $1 \%, 5 \%$ and $10 \%$ significance levels, respectively. The Breusch-Godfrey serial correlation LM tests residual autocorrelation. Null hypothesis: there is no residual autocorrelation. The Breusch-Pagan-Godfrey tests for heteroscedasticity. Null hypothesis: there is no heteroscedasticity.

\section{Analysis and Discussion}

According to the results, we find evidence that financial speculation accelerated copper price moves during the last price boom. In period 1, price (-1) and stockpile produced significant effects on copper prices changes. USDX, open interest and oil price didn't seem to play a significant role in explaining changes in copper prices. While in period 2 all variables are insignificant to explain changes in copper prices except historical copper prices. According to (Plunkert and Jones, 1999) during this periods copper market experienced stagnant world demand and rising inventories; LME intervention in the market that caused sharp price drop; strong global demand growth and sharp inventory decline. Furthermore commodity markets experienced Asian financial crisis and suffered from the early recession of 2000's. Humphreys (2015) refer to the period from 1975-2000 as the barren years for the mining industry because of economic slowdown and declining intensity of use of commodities by Western economies. These events could explain why some of the variables are insignificant.

In period 3, stockpile is not significant, whereas lagged price, speculation, US dollar exchange rate index and oil price are significant to explain changes in copper prices. In this period, strong economic growth in the world led to excess speculation and market fundamentals such as US dollar exchange rate market and oil market were very active in trading. All of these added to the upward pressure on price. Compared to other periods, the copper prices in this period fluctuated more violently and were more sensitive to different kinds of market information. The results support Guzmán and Silva (2017) that financial speculation have accelerated and amplified prices of copper movements between 2005 and 2008. In period 4, price lag and US dollar exchange rate index have a positive and negative effect respectively and 
are statistically significant whereas speculation, oil price and stockpile are not.

\section{Conclusion}

From the late 1990s to 2003, the LME copper prices sat below US\$2000 per tonne. It climbed sharply in 2004, peaking mid-2006 at almost US\$900/tonne and it has since been characterized by high fluctuations. This paper has examined the determinants of copper price changes over the time period from 1993 to 2016, with particular interest on the role played by financial speculation. Using least squares with breakpoints our study first test and estimate the number of breakpoints in real copper prices and then examines the effects of drivers of copper price changes under different breakpoints using least squares regression analysis. The results indicate that from January 1993 to December 2016, LME real copper spot prices have been characterized by structural changes and its determinants varies. Most importantly our study indicates that financial speculation amplified the fluctuation of prices during the price boom period contributing to the conclusion that fundamental forces alone cannot explain the price moves.

\section{Acknowledgement}

Support from the Ministry of Education, Culture, Sports, Science and Technology: Japan (MEXT) and Akita University New Frontier Leaders in Resources Program Fund is greatly acknowledged. An earlier version of this paper was presented at the $8^{\text {th }}$ SDIMI conference and the authors would like to thank participants for the comments raised therein. We also gratefully acknowledge comments from Juan Ignacio Guzmán.

\section{References}

Arezki, R., Loungani, P., van der Ploeg, R., \& Venables, T. (2014). Understanding International Commodity Price Fluctuations. Journal of International Money and Finance, (42), 1-8. https://doi.org/10.1016/j.jimonfin.2013.08.002

Bai, J., \& Perron, P. (1998). Estimating and testing linear models with multiple structural changes. Econometrica, 66(4), 47-78. https://doi.org/10.2307/2998540

Bai, J., \& Perron, P. (2003). Computation and Analysis of Multiple Change Models. Journal of Applied Econometrics 18, 1-22. https://doi.org/10.1002/jae.659

Charles River Associates. (1978). The economics and geology of mineral supply: An integrated framework for long-run policy analysis. Report N.327. Charles River, Boston, Massachusetts

Cifarelli, G., \& Paladino, G. (2009). Oil price dynamics and speculation: a multivariate financial approach. Energy Economics, 33(2), 363-372.

Dees, S., Gasteuil, A., Kaufmann, R. K., \& Mann, M. (2008). Assessing the factors behind oil price changes. European Central Bank working paper No 885.

Dees, S., Karadeloglou, P., Kaufmann, R. K., \& Sanchez, M. (2007). Modeling the world oil market: assessment of a quarterly econometric model. Energy Policy, 35(1), 178-191. https://doi.org/10.1016/j.enpol.2005.10.017

FCA. (2014). Commodity Markets Update, February 2014, Financial Conduct Authority.

Fisher, F., Cootner, P., \& Baily, M. (1972). An econometric model of the world copper industry. Bell J Econ 3(2), 568-609. https://doi.org/10.2307/3003038

Gilbert, C. L. (2010). Speculative influences on commodity futures prices 2006-2008, UNCTAD Discussion Paper No. 197, March.

Gocht, W., Zantop, H., \& Eggert, R. (1988). International Minerals Economics. Springer-Verlag Berlin Heidelberg, New York. https://doi.org/10.1007/978-3-642-73321-5

Guzmán, J. I., \& Silva, E. (2017). Copper price determination: fundamentals versus non-fundamentals. Mineral Economics Journal. https://doi.org/10.1007/s13563-017-0130-y

Haigh, M. S., Hranaiova, J., \& Overdahl, J. M. (2006). Price volatility, liquidity provision and the role of managed money traders in energy futures markets. CFTC paper

Hall, A. R., Osborn, D. R., \& Sakkas, N. (2013). Inference on structural breaks using information criteria. The Manchester School, 81(S3), 54-81. https://doi.org/10.1111/manc.12017

Humphreys, D. (2010). The great metals boom: a retrospective. Resource Policy, 35(1), 1-13. https://doi.org/10.1016/j.resourpol.2009.07.002

Humphreys, D. (2015). The Remaking Of The Mining Industry. Palgrave Macmillan. https://doi.org/10.1057/9781137442017

Kaufman, F. (2010, July). The food bubble. Harper's Magazine. 
Kaufmann, R. K., \& Ullman, B. (2009). Oil prices, speculation, and fundamentals: interpreting causal relations among spot and futures prices. Energy Economics, 31, 550-558. https://doi.org/10.1016/j.eneco.2009.01.013

Lynch, M. C. (2002). Causes of Oil Price Volatility. The Journal of Energy and Development, 28(1), 107-141.

Plunkert, P. A., \& Jones, T. S. (1999). Metal Prices in the United States Through 1998. U.S. Department of the Interior, U.S. Geological Survey

Radetzki, M. (2006). The anatomy of three commodity booms. Resources Policy 32(1), 56-64. https://doi.org/10.1016/j.resourpol.2006.06.003

Radetzki, M. (2013). The Perseverance of the Ongoing Metal and Mineral Boom. Mineral Economics, 25(2), 83-88. https://doi.org/10.1007/s13563-012-0020-2

Radetzki, M., \& Warell, L. (2017). A Handbook of Primary Commodities in the Global Economy. Cambridge University Press, Cambridge. https://doi.org/10.1017/9781316416945

Sanders, D. R., Boris, K., \& Manfredo, M. (2004). Hedgers, funds, and small speculators in the energy futures markets: an analysis of the CFTC's Commitments of Traders reports. Energy Economics, 26, 425-445. https://doi.org/10.1016/j.eneco.2004.04.010

Stevens, P. (2001). Micro-Managing Global Oil Markets: Is It Getting More Difficult? The Journal of Energy and Development, 26(2), 197-212.

Tan, C. S. (1987). An econometric analysis of the world copper market. Working Paper, World Bank.

Tilton, J. E., \& Guzmán, J. I. (2016). Mineral economics and policy. Resources for the Future, New York.

UNCTAD. (1998). UNCTAD Assesses effects of Asian Crisis on developing countries' trade. 07 May 1998. TAD/INF/PR/9813

UNCTAD. (2009). The financialization of commodity markets. In: Proceedings of The United Nations Conference on Trade and Development, Geneva, Switzerland.

Valencia, C. (2005). An econometric study of the world copper industry. Ph.D. Dissertation, Colorado School of Mines.

Vial, J. (1989). An Econometric Study of the World Copper Market. Ph.D. Dissertation. University of Pennsylvania, 1989.

Yao, Y. C. (1988). Estimating the number of change-points via Schwarz criterion. Statistics \& Probability Letters, 6, 181-189. https://doi.org/10.1016/0167-7152(88)90118-6

Zhang, Y., Fan, Y., Tsai, H. T., \& Wei, Y. M. (2008). Spill over effect of US dollar exchange rate on oil prices. Journal of Policy Modeling, 30, 973-991. https://doi.org/10.1016/j.jpolmod.2008.02.002

\section{Copyrights}

Copyright for this article is retained by the author(s), with first publication rights granted to the journal.

This is an open-access article distributed under the terms and conditions of the Creative Commons Attribution license which permits unrestricted use, distribution, and reproduction in any medium, provided the original work is properly cited. 